DOI: https://doi.org/10.32838/2523-4803/70-2-51

УДК 330.3:338.49

\title{
Шашина М.В.
}

кандидат економічних наук, доцент,

Національний технічний університет України

«Київський політехнічний інститут імені Ігоря Сікорського»

\section{Shashyna Maryna}

National Technical University of Ukraine

"Igor Sikorsky Polytechnic Institute"

\section{ІННОВАЦІЙНИЙ РОЗВИТОК ЯК ОСНОВА СТРУКТУРНОЇ МОДЕРНІЗАЦІЇ РЕГІОНАЛЬНОЇ ЕКОНОМІКИ}

Статтю присвячено розгляду основних теоретичних параметрів взаємодії інноваційного розвитку та структурної модернізації регіональної економіки. Виявлено сучасні тенденції щзодо здійснення та впровадження структурних зрушень на засадах інновацій. Охарактеризовано специфіку протікання інноваційного процесу залежно від рівня розвитку регіону. Наголошено на концептуальних засадах реалізації структурної модернізації, використовуючи сучасні тенденції гармонізації горизонтальних та вертикальних чинників структурних зрушень, до яких спонукає інноваційний розвиток. Виявлено спещифічні характеристики спеціалізації та диференціації, щзо сформувалися у результаті нових організаційних форм управління та взаємодї регіональних суб'єктів, а також техніко-технологічного розвитку.

Ключові слова: інновації, структурна модернізація, регіональна економіка, спеціалізація, диференц̧іація.

Постановка проблеми. Виклики сьогодення не залишають Україні інших альтернатив окрім інноваційного розвитку, що ставить регіони на якісно новий рівень соціально-економічного становища, змінює показники якості життя та формування інноваційних систем. Звичайно, цей шлях є невід'ємною частиною загальносвітового процесу, i, як зазначає С. Тульчинська, «.було б неправомірним відривати економічні процеси, які проходять в Україні, від світової практики, та наголошувати, що нашою країною визначе- 
ний свій неповторний шлях розвитку науки і техніки, пов'язаний із застосуванням унікальних форм організації та управління» [7, с. 56].

Структурні зміни досить часто стають предметом обговорення як урядовців, так і науковців, тому, звичайно, у різних країнах $є$ вже накопичений відповідний досвід, за якого інновації стають їх рушієм, але, 3 іншого боку, також наявні структурні відмінності між регіонами, які спричинили нове бачення прогресивних структурних змін, виявлення впливу інновацій на виникнення структурних зрушень та взаємозв'язку інноваційного розвитку і структурної модернізації регіональної економіки.

Аналіз останніх досліджень і публікацій. Завдяки дослідженням сучасних вітчизняних науковців сформувався досить потужний пласт наукових робіт, що розкривають специфіку й сутність інноваційного розвитку та структурної модернізації у розрізі регіональної економіки. Так, С. Тульчинська зосереджувала свою увагу на функціонуванні інтелектуально-інноваційної системи регіонів. А. Прокопюк визначив, як має змінитися регіональна політика, що призводить до структурної модернізації регіонів під впливом євроінтеграції. Т. Романова виявила параметри економічного розвитку регіонів, що формуються під час інтеграційних процесів.

Ураховуючи величезний теоретичний здобуток означених авторів, а також багатьох інших науковців, слід звернути увагу на сучасні теоретичні точки дотику інноваційного розвитку та структурної модернізації регіональної економіки, у чому відбулися зміни теоретичних поглядів на основі емпіричного досвіду.

Формулювання цілей статті. Мета статті - сформулювати теоретичні засади взаємозв'язку інноваційного розвитку та структурної модернізації регіональної економіки, визначити сучасні тенденції структурних змін під впливом інновацій, розглянути напрями реалізації інноваційного розвитку в регіональному просторі.

Виклад основного матеріалу. На основі емпіричних досліджень встановлено, що структурні зміни та інновації тісно пов'язані між собою [4; 6; 8; 9], оскільки знання $€$ центральним ресурсом, а структури змінюються завдяки новоствореним знанням, а також новим технічним, організаційним та соціальним рішенням, тобто інноваціям. Структурні зміни та інновації - це процеси, на які можна впливати, вони залежать від зовнішніх чинників (становища та тенденцій розвитку в інших регіонах, розвитку ринку), тому має значення специфіка середовища здійснення інноваційного розвитку.

За відповідними теоріями локації та регіонального зростання (Й. Тюнена, В. Крісталлера, А. Леша, А. Маршела, А. Бьовентера та ін.) фактори агломерації, тобто регіональні переваги від спеціалізації чи диверсифікації, викликають кумулятивні процеси, які генерують імпульси зростання, що спонукають зростання продуктивності праці за рахунок внутрішньої віддачі, таким чином, призводять до структурних зрушень, які, своєю чергою, за рахунок чинників взаємодії між регіо- нами можуть призвести до позитивних або негативних структурних змін в іншому регіоні, що визначає стимулююче або стримуюче зростання. Саме інноваційний розвиток, що формує нові знання та людський капітал, визначає диференціацію регіонів; своєю чергою, знання, підкріплені дослідженнями, імітацією, адаптацією та практичним досвідом, під час перетікання створюють позитивний зовнішній ефект та стимулюють процеси структурної модернізації регіонального простору.

3 іншого боку, всі структурні впливи, які мають відношення до економіки та суспільства, впливають і на регіональні структурні зміни. У контексті сучасного регіонального розвитку це стосується не лише змін у галузевій структурі регіонів, а також структури інфраструктури знань (дослідницькі та посередницькі організації) i можливостей їх використання. Щодо структурної модернізації регіональної економіки, то на передній план виходять комунікативні інфраструктури, засновані на швидких мережах передачі даних. Але існує також обмеження можливостей до змін, що спричинено способами та інструментами, які використовують для ініціювання структурних зрушень, а також тенденції у розподілі державних та приватних коштів. Тому постає питання щодо пошуку джерел і визначення умов, за яких здійснення структурних змін на засадах інноваційного розвитку призводить до структурної модернізації регіональної економіки.

Звичайно структурні зміни властиві регіонам із різним рівнем соціально-економічного розвитку. Досить часто одним із пріоритетних завдань щодо регіонального розвитку $€$ його нерівномірність та незбалансованість. Для слабких регіонів досить важливими є питання, як у результаті структурних змін не поглибити цей розрив. Тому досить часто наголошують на тому, що імпульси інноваційного розвитку можуть виникати за рахунок взаємодії з більш потужними регіонами. Але тут також наявні певні загрози, оскільки високий рівень відкритості регіонів [1;2] може призвести до ситуацій, коли з відносно слабких регіонів відбувається перетікання ресурсів до економічно сильних регіонів, що є характерним для України, тому важливим $є$ використання як внутрішніх, так і зовнішніх чинників структурних зрушень. Наприклад, підтримка університетів щодо сприяння їхній інноваційній діяльності не дасть очікуваного ефекту від співпраці з регіональною економікою, якщо регіональні організації виявляться не готовими для цього.

Христоматійним прикладом означеного фактору стала економічна реформа в Японії (1950-1960рр.), коли вона за короткий час наздогнала великі індустріальні країни, імпортуючи винаходи та освоївши нові технології й знання. Ще до кінця 40-х років цій країні вдалося створити умови для подальшого інноваційного розвитку за рахунок створення відповідних умов через підвищення кваліфікації робочої сили, розвиток творчих здібностей керівників, що дало змогу адаптувати та впровадити тогочасні нові знання і зарубіжні технологічні досягнення, зокрема в галузі електроніки. 
У подальшому це сприяло збільшенню щорічної продуктивності праці на 9,9\% [5].

Для України нині характерний той шлях, який Японія вже пройшла до початку двохтисячних років, формуючи сприятливі передумови інноваційного розвитку на засадах інформатизації суспільства, зокрема щодо прийняття інформаційного законодавства, оптимізації державного та регіонального управління з використанням інформаційних мереж, доступу до інформації громадян та захисту конфіденційних відомостей, переходу до мовлення у високій якості. Звичайно, як наголошує С. Тульчинська, інноваційний розвиток регіональної економіки не можливий без відповідного задоволення потреб людей у різноманітних благах [8, с. 227]. Відповідно, якість життя населення створює передумови для відтворення робочої сили, зростання продуктивності праці та інноваційного розвитку щодо структурної модернізації регіонів.

На думку Е. Суміна та Д. Заблікова [6, с. 518], диверсифікація регіональної економіки передбачає формування багатопромислової кризовостійкої економічної системи регіонів та всебічний розвиток галузей, які мають високу додану вартість. Також автори наголошують, що саме даний вибір напряму структурної модернізації сприяє розвитку міжрегіональної та внутрішньорегіональної конкуренції, що призведе до збільшення товарних ринків та попиту серед різних верст населення.

Сучасні трактування спеціалізації полягають у площині смарт-спеціалізації, яка, на думку Х. Патицької, полягає у визначенні можливостей регіону до генерації нових видів діяльності через виявлення пріоритетів локальної концентрації і максимально ефективного використання ресурсів [3].
Якщо початкові завдання реалізації інноваційного процесу передбачали акценти взаємовиключення спеціалізації та диференціації, вибираючи горизонтальну чи вертикальну форму їх упровадження, то сучасні виклики потребують їх поєднання, що мінімізує можливість прояву їхніх недоліків (вибір неперспективного напряму, залежність від державної підтримки, наявність бар'єрів поширення інновацій, небезпека розпорошення ресурсів тощо) та підсилює переваги (локалізація, мінімізація ризиків, швидкість поширення інформації, економія на масштабах, максимальне включення суб' єктів регіональної господарської системи до процесу суспільного відтворення). Використання підходу на засадах поєднання диверсифікації та спеціалізації потребує виділення деяких ключових позицій, завдяки яким відбувається структурна модернізація регіонального простору на засадах інноваційного розвитку (рис. 1).

Як видно з рисунку, для структурної модернізації важливим $є$ адаптивність регіонального простору до структурних змін, заснованих на інноваціях, що стає можливим за рахунок системного врахування міжрегіональних взаємозв'язків, інноваційної компетентності нових та існуючих фірм, взаємодії промоутерів та посередників інноваційного розвитку, створення регіональних інтегрованих дослідницьких центрів та використання можливостей цифрової інфраструктури.

Висновки. Основою розуміння структурних зрушень, що спричиняють структурну модернізацію регіональної економіки, стає інноваційний розвиток, який спрямований на формування нових знань та якості людського капіталу. Сучасний підхід до теорій локацій i розвитку регіону формується під впливом нових вимог

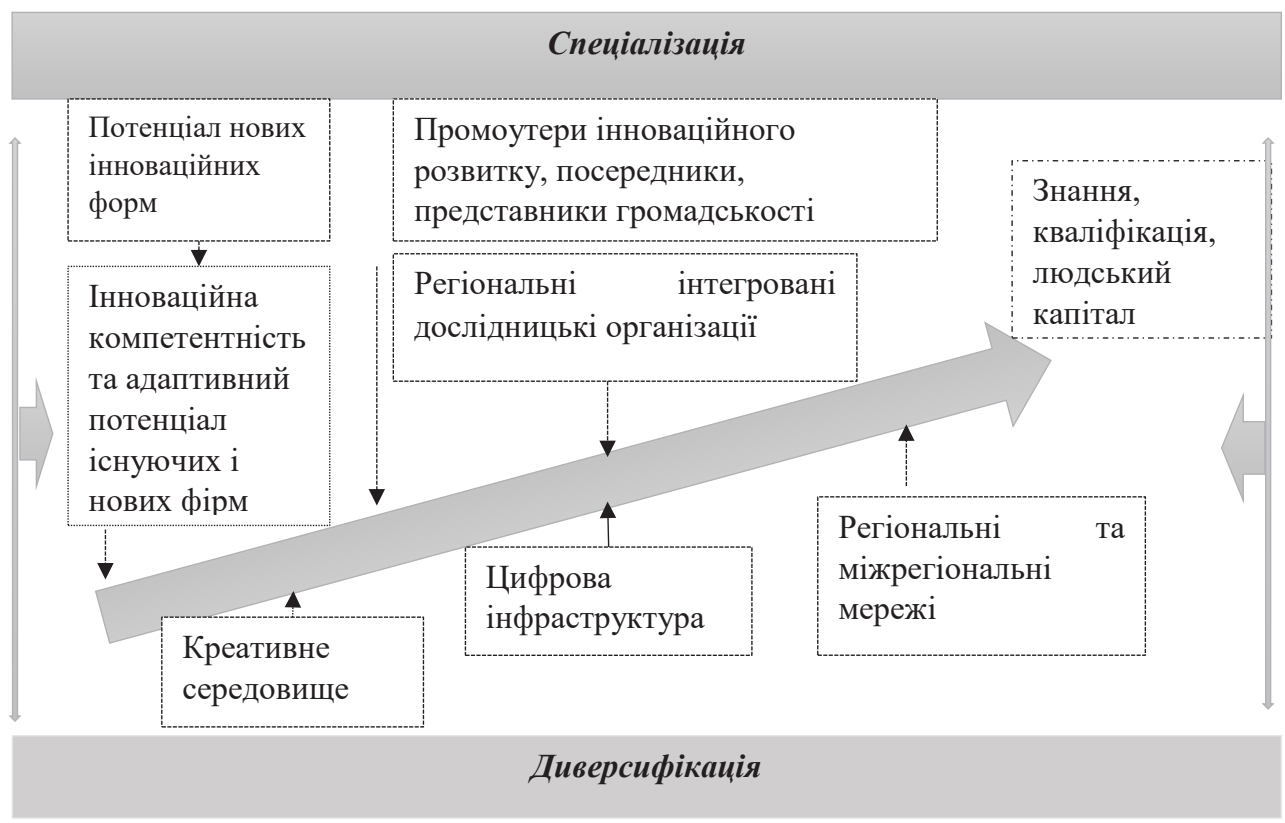

Рис. 1. Засади інноваційного розвитку структурної модернізації регіональної економіки

Джерело: розроблено автором на основі [10] 
до джерел та умов, за яких відбуваються структурні зрушення в регіональному просторі, що характеризуються прогресивними змінами. Відкритість регіонів, поява нових форм взаємодії суб'єктів господарювання та споживачів у регіональному та міжрегіональному просторі, диференціація за рівнями соціально-економічного розвитку і перерозподіл функціональних повноважень управління у розрізі децентралізації спровокували пошук стійких адаптивних форм упровадження інновацій, використовуючи сучасні технікотехнологічні заходи. Так, відбувається пошук консолі- дації класичних стратегій розвитку регіону на засадах спеціалізації та децентралізації з визначенням ключових параметрів, які мінімізують перетікання ресурсів зі слабкого регіону в більш сильний та стимулюють виявлення і розвиток локальних чинників активізації регіональної господарської системи.

Подальші дослідження слід спрямувати на більш глибокий аналіз впливу функціональних завдань нових інституціональних утворень відповідно рівнів розвитку регіонів, що призведе до нівелювання диференціації між ними.

Список літератури:

1. Бурик 3.М. Формування концепції сталого розвитку регіону. Теорія та практика державного управління $i$ місиевого самоврядування. 2014. № 1. URL : http://nbuv.gov.ua/UJRN/Ttpdu_2014_1_22 (дата звернення: 15.11.2018).

2. Механізм реалізації регіональної структурної політики / за ред. А.Ф. Мельник. Тернопіль : ТНЕУ, 2015. 343 с.

3. Патицька Х.О. Стратегія смарт-спеціалізації в контексті забезпечення конкурентоспроможності регіону: теоретичний аспект. Ефективна економіка. 2019. № 11. URL : http://www.economy.nayka.com.ua/?op=1\&z=7399 (дата звернення: 10.03.2020).

4. Паулик А.Я. Проблеми та перспективи розвитку інноваційного потенціалу економіки регіону. Науковий вісник Мукачівського державного університету. Економіка. 2015. Вип. 2(4). Ч. 1. С. 169-175.

5. Сигето Цуру. Конец японского «экономического чуда» / пер. с японского В.Б. Рамзеса. Москва : Прогресс. 1981. $272 \mathrm{c}$.

6. Сумина Е.В., Заблинков Д.В. Инновационное развитие региона: потребности диверсифицированного роста экономики Сибири в условиях реиндустриализации. Весник СибГАУ. 2015. Т. 16. № 2. С. 515-522.

7. Тульчинська С.О. Інтелектуально-інноваційна модернізація економіки України: теоретико-методологічні аспекти : монографія. Київ : НТУУ «КПІ». 2009. 488 с.

8. Тульчинська С.О. Органічність функціонування інтелектуально-інноваційної системи регіонів : монографія. Херсон : Вишемирський В.С., 2012. 400 с.

9. Innovation management in regional development / V.G. Kovalchuk et al. URL : http://fkd.org.ua/article/view/190948 (дата звернення: 10.03.2020).

10. Koschatzky K. Innovation-based regional structural change. Theoretical reflections, empirical findings and political implications. URL : https://www.isi.fraunhofer.de/content/dam/isi/dokumente/ccp/unternehmen-region/2018/ap_r1_2018. pdf (дата звернення: 12.11.2019).

\section{References:}

1. Bury'k Z. M. (2014), Formuvannia kontseptsiï staloho rozvytku rehionu [Formation of researched sustainable develop]. Teoriya ta prakty 'ka derzhavnogo upravlinnya i miscevogo samovryaduvannya, no. 1. Available at: http://nbuv.gov.ua/UJRN/ Ttpdu_2014_1_22 (accessed: 15.11.2018).

2. Mel`ny`̄ A. (2015) Mexanizm realizaciyi regional`noyi strukturnoyi polity`ky` [Mechanism for implementation of regional structural policy]. TNEU, Ternopil.

3. Paty`cz`ka X.O. (2019), Stratehiia smart-spetsializatsii v konteksti zabezpechennia konkurentospromozhnosti rehionu: teoretychnyj aspekt [A strategy for maintaining smart specialization in the context of regions competition]. Available at: http://www.economy.nayka.com.ua/?op=1\&z=7399 ( accessed: 10.03.2020).

4. Pauly`k A. (2015), Problemy ta perspektyvy rozvytku innovatsijnoho potentsialu ekonomiky rehionu [Problems and prospects of development innovative potential of regional economy]. Naukovyi visnyk Mukachivskoho derzhavnoho universytetu. Ekonomika, vol. 2 (4), no. 1, pp. 169 - 175.

5. Sigeto Curu (1981), Konec japonskogo «jekonomicheskogo chuda» [The end of the Japanese "economic miracle"]. Progress, Moscow, Russia.

6. Sumina E. V. and Zablinkov D.V. (2015) Innovacionnoe razvitie regiona: potrebnosti diversificirovannogo rosta jekonomiki Sibiri v uslovijah reindustrializacii [Innovative development of the region: the needs of diversified economic growth in Siberia in the context of reindustrialization]. Vesnik SibGAU, vol.16. (2), pp. 515 - 522.

7. Tulchynska S.O. (2009), Intelektual'no-innovatsijna modernizatsiia ekonomiky Ukrainy: teoretyko-metodolohichni aspekty [Intellectual-innovate modernization of the Ukraine economy: theoretical and methodological aspects]. NTUU "KPI", Kyiv.

8. Tulchynska S.O. (2012), Orhanichnist' funktsionuvannia intelektual'no-innovatsijnoi systemy rehioniv [Organic functioning of the intellectually innovative system of regions]. Vyd-vo "PP Vyshemyrs'kyj V.S", Kherson.

9. Kovalchuk V. G., Naipak D. V., Ivanova A. S., Volkova M. V. and Svitlychna K. S. (2019) Innovation management in regional development. Available at: http://fkd.org.ua/article/view/190948 (accessed: 10.03.2020).

10. Koschatzky K. (2018) Innovation-based regional structural change - Theoretical reflections, empirical findings and political implications. Available at: https:/www.isi.fraunhofer.de/content/dam/isi/dokumente/ccp/unternehmen-region/2018/ ap_r1_2018.pdf (accessed: 12.11.2019). 


\section{ИННОВАЦИОННОЕ РАЗВИТИЕ КАК ОСНОВА \\ СТРУКТУРНОЙ МОДЕРНИЗАЦИИ РЕГИОНАЛЬНОЙ ЭКОНОМИКИ}

Статья посвящена рассмотрению основных теоретических параметров взаимодействия инновационного развития и структурной модернизации региональной экономики. Выявлены современные тенденции осуществления и внедрения структурных сдвигов на основе инноваций. Охарактеризована специфика протекания инновационного процесса в зависимости от уровня развития региона. Отмечены кониептуальные основы реализации структурной модернизации, используя современные тенденции гармонизации горизонтальных и вертикальных факторов структурных сдвигов, к которым побуждает инновационное развитие. Обнаружены специфические характеристики специализации и дифференциации, которые сформировались в результате новых организационных форм управления и взаимодействия региональных субъектов, а также технико-технологического развития.

Ключевые слова: инновации, структурная модернизация, региональная экономика, специализация, дифференцииация.

\section{INNOVATIVE DEVELOPMENT AS THE BASIS OF STRUCTURAL MODERNIZATION OF THE REGIONAL ECONOMY}

A new interpretation of the location theory and regional development need to formulate theoretical bases of the relationship between innovation development and structural modernization of regional economy. This paper focuses on the modern trend characteristics of structural changes under the influence of innovation and innovative development directions in regional space. Using theories of locations and region development is characterized by the emergence of new interaction subject forms of regional economy, the dependence on the innovative development diffusion of the region socio-economic level and information infrastructure. It is revealed that modern trend in structural modernization of regional economy aimed at finding sustainable and adaptive forms of innovation through the use of modern technical and technological measures. It is also noted that any structural effects that are relevant to the economy and society, affect both regional structural changes. In the context of modern regional development this applies not only to changes in the sectoral structure of regions, the structure of the knowledge infrastructure and its use. For weak regions it becomes relevant in the search for new forms of interaction with more powerful regions that would lead to threatening the flow of resources. Initial tasks to realization of innovative process envisaged the accents of exception specialization or differentiation, electing the horizontal or vertical form of their introduction, then modern calls need their combination that minimizes possibility of display of their defects. Modern trend in structural modernization of regional space involve a combination of two basic directions of strategic development, because it is such a consolidated approach can ensure innovative development. Therefore, it becomes important to take into account interregional, innovation competence of new and existing firms, the interaction of promoters and facilitators of innovation development, creation of regional integrated research centers and opportunities of digital infrastructure. Further deeper analysis task the new institutional formations accordingly of regions development levels, that will result in leveling of differentiation between them.

Key words: innovation, structural modernization, regional economy, specialization, differentiation. 